\title{
Mass Spectral Fragmentation \\ of the Intravenous Anesthetic Propofol and Structurally Related Phenols
}

\author{
Lakshmikant Bajpai \\ Department of Anesthesiology, University of Florida, Gainesville, Florida, USA \\ Manoj Varshney* \\ Engineering Research Center, University of Florida, Gainsville, Florida, USA \\ Christoph N. Seubert \\ Department of Anesthesiology, University of Florida, Gainesville, Florida, USA \\ Stanley M. Stevens, Jr. \\ ICBR Protein Core Laboratory, University of Florida, Gainesville, Florida, USA
}

Jodie V. Johnson

Spectroscopy Services, Department of Chemistry, University of Florida, Gainesville, Florida, USA

Richard A. Yost

Department of Chemistry, University of Florida, Gainesville, Florida, USA

\section{Donn M. Dennis}

Departments of Anesthesiology, Pharmacology, and Experimental Therapeutics, University of Florida, Gainesville, Florida, USA

Propofol (2,6-diisopropyl phenol) is a widely used intravenous anesthetic. To define its pharmacokinetics and pharmacodynamics, methods for its quantitation in biological matrixes have been developed, but its pattern of mass spectral fragmentation is unknown. We found that fragmentation of the $[\mathrm{M}-\mathrm{H}]^{-}$ion $(\mathrm{m} / \mathrm{z}$ 177) of propofol in both APCI MS/MS and ESI MS/MS involves the stepwise loss of a methyl radical and a hydrogen radical from one isopropyl side chain to give the most intense product ion, $\left[\mathrm{M}-\mathrm{H}-\mathrm{CH}_{4}\right]^{-}$, at $\mathrm{m} / \mathrm{z} 161$. This two-step process is also the preferred mode of fragmentation for similar branched alkyl substituted phenols. This mode of fragmentation of the $[\mathrm{M}-\mathrm{H}]^{-}$ion is supported by three independent lines of evidence: (1) the presence of the intermediary $\left[\mathrm{M}-\mathrm{H}-\mathrm{CH}_{3}\right]^{-}$radical ion under conditions of reduced collision energy, (2) the determination of the mass of the predominant $\left[\mathrm{M}-\mathrm{H}-\mathrm{CH}_{4}\right]^{-}$product ion by high resolution mass spectrometry, and (3) the pattern of product ions resulting from further fragmentation of the $\left[\mathrm{M}-\mathrm{H}-\mathrm{CH}_{4}\right]^{-}$product ion. Phenols with a single straight chain alkyl substituent, in contrast, undergo $\beta$ elimination of the alkyl radical irrespective of the length of the alkyl chain, yielding the most intense product ion at $\mathrm{m} / \mathrm{z} 106$. This product ion represents a special case of a stable intermediary radical for the two-step process described for branched side chains, because further elimination of a hydrogen radical from the $\beta$ carbon is not possible. (J Am Soc Mass Spectrom 2005, 16, 814-824) (c) 2005 American Society for Mass Spectrometry

$\mathrm{P}$ ropofol (2,6-diisopropyl phenol) is an intravenous anesthetic with a phenolic structure. It is used for both induction [1] and maintenance [2] of general anesthesia. It is also useful for sedation [3]

Published online May 3, 2005

Address reprint requests to Dr. D. M. Dennis, Department of Anesthesiology, University of Florida College of Medicine, Box J-100254, JHMHC, 1600 SW

Archer Road, Gainesville, FL 32610-0254, USA. E-mail: DDennis@ufl.edu

* Permanent address: Department of Chemistry, Hamdard University, New Delhi 110061, India. as a supplement to regional anesthesia and in critically ill patients confined to intensive care units. The patient loses consciousness 30 to $50 \mathrm{~s}$ after receiving the drug and remains asleep for about 4 to 6 min [1, 2]. Even though a single dose of propofol has a short duration of action and produces fast recovery from anesthesia, propofol is not metabolized in a few minutes. It is present in blood, adipose tissues, liver, and brain for a few hours, its concentration decreasing with time [4]. To study this tissue distribution 
and the pharmacokinetics of propofol, it is necessary to quantitate it precisely.

Various methods have been reported for the quantitation of propofol in plasma or blood: high performance liquid chromatography (HPLC) with ultraviolet absorbance [5], fluorescence [6], or electrochemical detection [7]; gas chromatography (GC) with atomic emission [8] or mass spectrometric (MS) detection [9]; capillary GC or head-space GC [10] with solid-phase microextraction. The coupling of a MS detector to the HPLC system offers a more selective analytical technique compared with HPLC methods using traditional detectors. We attempted to develop an LC/MS method for the detection of propofol, but observed interfering peaks at the propofol retention time and a high background while applying the method to human plasma samples. A second stage of mass analysis (MS/MS) enhanced selectivity and provided an improved signal-to-noise ratio compared with single-stage MS. This technique also reduced the need for complete resolution of the analyte from the endogenous matrix compared to HPLC with other modes of detection. We recently reported this LC/MS/MS method for detection and quantitation of propofol in human plasma [11].

Phenols are known to readily form negative ions in the gas phase, and there are several reports on their negative ion chemical ionization mass spectra [1214]. One report on the fragmentation of phenolic anions in the gas phase is restricted to phenol only [12]. Reports on negative ion LC/MS for the identification of propofol using APCI for ionization fail to discuss its fragmentation [15, 16]. Fragmentation of the $[\mathrm{M}+\mathrm{H}]^{+}$ion of sterically hindered phenols formed by chemical ionization using methane or butane as the reagent gas $[17,18]$ indicate the formation of product ions by the loss of a methyl radical at the $\beta$ carbon of substituent side chains. There are some reports on the gas-phase decomposition of alkoxide ions generating hydrogen and methane as the main fragmentation by-products [19-21]. Based on a deuterium isotope effect study, Brauman and coworkers reported that the infrared multiphotoninduced elimination of methane or hydrogen from the $t$-butoxide negative ion proceeds by a stepwise mechanism [19, 20] involving bond cleavage as the first step and a subsequent hydrogen transfer reaction from an intermediate ion-molecule complex. This mechanism was further supported in a study of isotope effects using a sector mass spectrometer and ab initio calculations [21]. During development of our LC/MS/MS method for the determination of propofol that used negative ion atmospheric pressure chemical ionization (APCI), we observed a fragmentation pattern that was entirely different from that reported for other phenols [22]. ${ }^{\text {TTherefore, }}{ }^{\circ} \mathrm{we}^{\circ}$ undertook a detailed study of the mass spectral fragmentation of the $[\mathrm{M}-\mathrm{H}]^{-}$ions of propofol and structurally related phenols in APCI and electrospray ionization (ESI) modes and confirmed the mass of the proposed $\left[\mathrm{M}-\mathrm{H}-\mathrm{CH}_{4}\right]^{-}$product ion using high resolution mass spectrometry.

\section{Experimental}

\section{Chemicals}

Propofol and most phenols used in this study were purchased from Sigma-Aldrich Co. (St. Louis, MO). 4-Vinyl phenol, 4-n butyl phenol, 4-n pentyl phenol, and 4-n heptyl phenol were purchased from Lancaster, Inc. (Windham, NH). HPLC-grade methanol was purchased from Fischer Scientific Co. (Hampton, NH).

\section{Mass Spectrometry}

All spectra were recorded in negative ion mode, as phenols are much less sensitive towards ionization in positive ion mode by the addition of a proton. APCI and ESI spectra were acquired on three different mass spectrometers, a triple quadrupole instrument, a hybrid quadrupole/time of flight instrument, and a quadrupole ion trap instrument as described below.

\section{Triple Quadrupole Tandem Mass Spectrometry}

Most of the spectra were collected with a triple quadrupole mass spectrometer (API 4000, Applied Biosystems/MDS Sciex, Foster City, CA) equipped with the manufacturer's APCI or ESI probe (also described as turbo ion spray by the manufacturer). APCI conditions were a vaporizer temperature of $250{ }^{\circ} \mathrm{C}$ and a corona discharge current of $-5 \mu \mathrm{A}$. Nitrogen supply pressures were 30,48 , and 6 psi for curtain, nebulizing, and collision gas, respectively. Collision energies ranged from 30 to $45 \mathrm{eV}$ and declustering potentials from -68 to $-88 \mathrm{~V}$. ESI conditions were a vaporizer temperature of $300^{\circ} \mathrm{C}$, an ion spray voltage of $-4500 \mathrm{~V}$, and a declustering potential of -68 to $-88 \mathrm{~V}$. Nitrogen supply pressures were 45,48 , and 6 psi for nebulizing, auxiliary, and collision gas, respectively. Collision energies ranged from 30 to $45 \mathrm{eV}$.

Spectra were recorded using scan ranges suitable for each particular analyte. Product ion scans were recorded from $\mathrm{m} / \mathrm{z} 50$ to a value approximately $10 \%$ greater than that of the parent ion. Normal MS scans covered a range from $\mathrm{m} / \mathrm{z} 50$ to a value twice the molecular weight of the analyte. Parent ion scans were acquired over a limited scan range of $m / z 100$ to 200, with masses set appropriately for the ions of interest. Scan rates for both normal mass and product ion spectra were typically on the order of $200 \mathrm{~m} / \mathrm{z}$ units per second. Samples were prepared in methanol at an approximate concentration of $500 \mathrm{ng} / \mathrm{ml}$. They were introduced into the ion source at a flow rate of $40 \mu \mathrm{L} / \mathrm{min}$ by using a syringe pump (Harvard model 22, Harvard Apparatus, Holliston, MA). Spectra were acquired in profile mode with a $1 \mathrm{~s}$ acquisition 

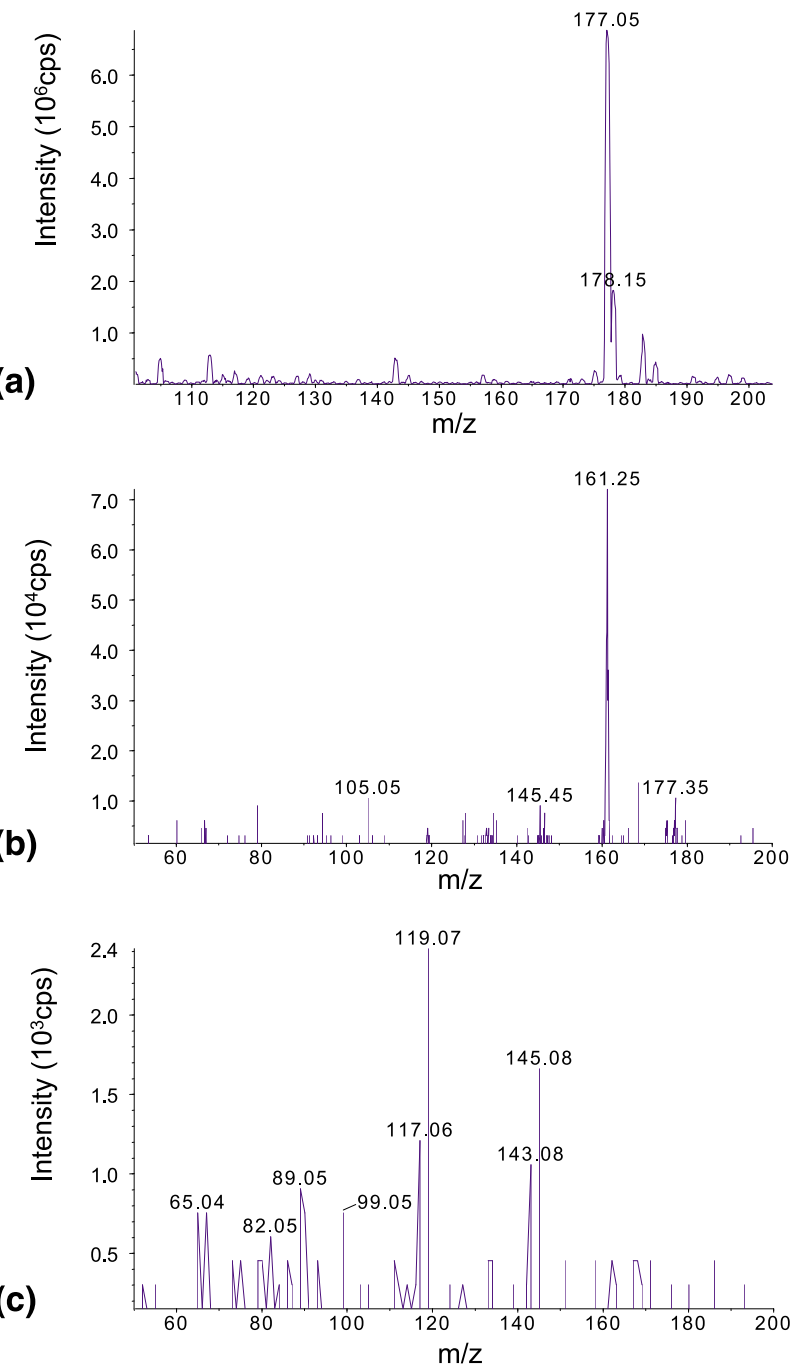

Figure 1. Mass spectral fragmentation of the $[\mathrm{M}-\mathrm{H}]^{-}$ion of propofol with APCI in negative ion mode on a triple quadrupole mass spectrometer. (a) Normal mass spectrum; (b) product ion spectrum of $\mathrm{m} / \mathrm{z} 177$, dominated by a single product at $\mathrm{m} / \mathrm{z} 161$; (c) product ion spectrum of $\mathrm{m} / \mathrm{z} 161 ; \mathrm{m} / \mathrm{z} 161$ was selected with quadrupole 1 and further fragmented.

duration typically by summation of 10 individual scans.

\section{HPLC/Quadrupole Ion Trap Tandem Mass Spectrometry}

The second mass spectrometer was a ThermoFinnigan (San Jose, CA) LCQ-quadrupole ion trap mass spectrometer. Tandem mass spectrometry data were obtained with both negative ESI and negative APCI. For ESI instrument settings were: spray voltage 3.3 $\mathrm{kV}$, nitrogen sheath gas 60 (instrument parameter), auxiliary gas 5 , heated capillary voltage $-15 \mathrm{~V}$, temperature $250{ }^{\circ} \mathrm{C}$, and tube lens offset $20 \mathrm{~V}$. For APCI, the vaporizer temperature was $300{ }^{\circ} \mathrm{C}$, the heated capillary temperature was $250^{\circ} \mathrm{C}$, the discharge needle was operated at $6.0 \mathrm{kV}$ and $6.0 \mu \mathrm{A}$. The other settings were nitrogen sheath gas 25 , auxiliary gas 0 , heated capillary voltage $15 \mathrm{~V}$, and tube lens offset $0 \mathrm{~V}$. Tandem mass spectra were obtained utilizing the advanced features of the scan function. In general, the ions were isolated with a 2.5 or $3.0 \mathrm{u}$ window and then collision-induced dissociation (CID) was performed at a Mathieu q of 0.4 or 0.45 with a resonant excitation voltage of 43 to $47 \%$ maximum (software parameter) applied for $30 \mathrm{~ms}$. For some weak $\mathrm{MS}_{\mathrm{n}}$ spectra, the isolation window widths for the earlier generation product ions were increased to increase the sensitivity.

Sample introduction was via HPLC utilizing an Agilent (Palo Alto, CA) 1100 series binary pump with mobile phase A being $\mathrm{H}_{2} \mathrm{O}$ and mobile phase $\mathrm{B}$ being methanol. The HPLC flow rate was $0.15 \mathrm{~mL} / \mathrm{min}$. A reverse-phase gradient liquid chromatographic separation $[\mathrm{A}: \mathrm{B}(\mathrm{min})=95: 5(0)$ to $5: 95(45-60)]$ was initially performed on a Phenomenex (Torrace, CA) Synergi $4 \mu$ Hyrdro-RP 80 A column $(2 \mathrm{~mm} \times 150$ $\mathrm{mm})$ with a $\mathrm{C}_{18}$ guard column $(2 \mathrm{~mm} \times 4 \mathrm{~mm})$ to ascertain purity. As no significant mass spectrometric interferences were found, the remaining analyses were performed with the $\mathrm{C}_{18}$ guard column men-

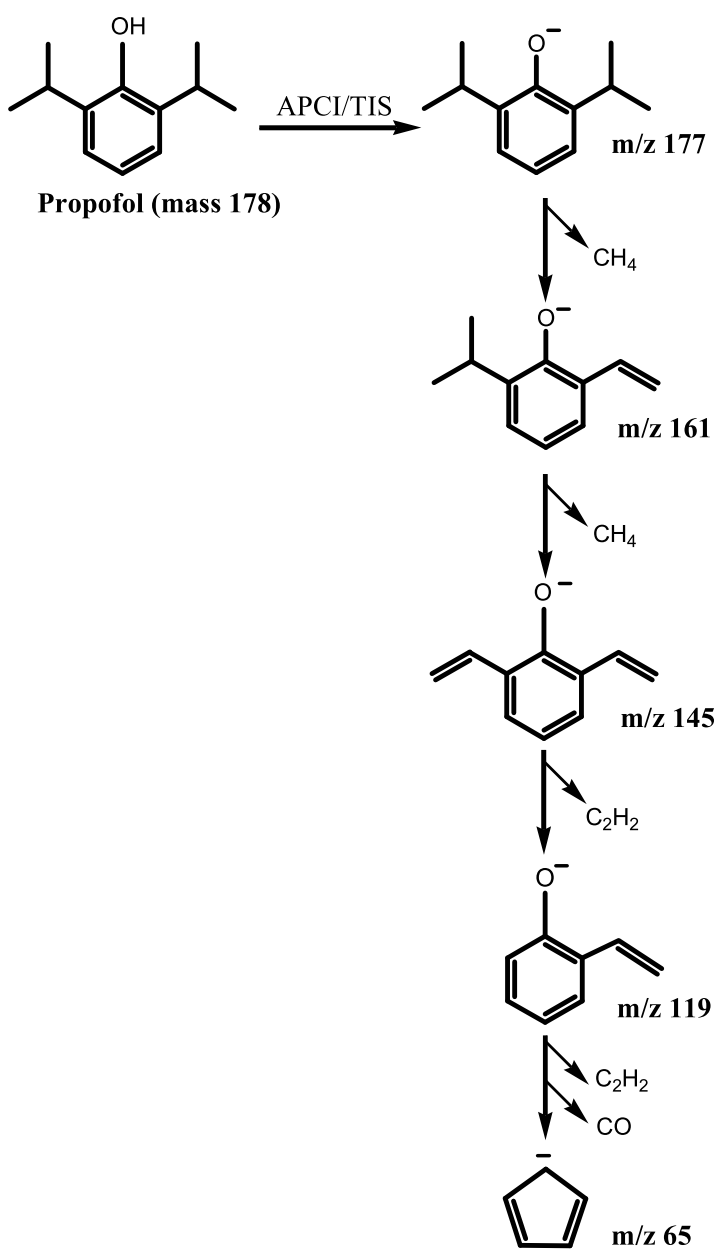

Scheme 1 
Table 1. Mass spectral fragmentation of propofol and structurally related phenols

\begin{tabular}{|c|c|c|c|c|c|c|}
\hline $\begin{array}{l}\text { Sample } \\
\text { number }\end{array}$ & Structure & Phenol & $\begin{array}{l}\text { Molecular } \\
\text { weight } \\
\text { (g/mol) }\end{array}$ & $\begin{array}{l}\text { Quasi-molecular } \\
\text { lon }[\mathrm{M}-\mathrm{H}]^{-}(\mathrm{m} / \mathrm{z})\end{array}$ & $\begin{array}{l}\text { Most abundant } \\
\text { product ion } \\
(\mathrm{m} / \mathrm{z})\end{array}$ & $\begin{array}{c}\text { Elimination } \\
\text { product } \\
\text { (mass) }\end{array}$ \\
\hline 1 & & $\begin{array}{l}\text { 2,4,6-Tritertiary butyl } \\
\text { phenol }\end{array}$ & 262.4 & 261 & 245.4 & 15.6 \\
\hline 2 & & $\begin{array}{l}\text { 2,6-Ditertiary butyl-4- } \\
\text { methyl phenol }\end{array}$ & 220.4 & 219.1 & 203.1 & 16 \\
\hline 3 & & $\begin{array}{l}\text { 2,6-Ditertiary butyl } \\
\text { phenol }\end{array}$ & 206.3 & 205.1 & 189.2 & 15.9 \\
\hline 4 & & $\begin{array}{l}\text { 3,5-Ditertiary butyl } \\
\text { phenol }\end{array}$ & 206.3 & 205.1 & 189.2 & 15.9 \\
\hline 5 & & $\begin{array}{l}\text { 2,6-Diisopropyl } \\
\text { phenol (propofol) }\end{array}$ & 178.3 & 177.1 & 161.2 & 15.9 \\
\hline 6 & & $\begin{array}{l}\text { 2-Isopropyl-4-methyl } \\
\text { phenol }\end{array}$ & 150.2 & 149.2 & 133.1 & 16.1 \\
\hline 7 & & 2-Isopropyl phenol & 136.2 & 135 & 119.1 & 15.9 \\
\hline 8 & & 3-Isopropyl phenol & 136.2 & 135 & 119.1 & 15.9 \\
\hline 9 & & $\begin{array}{l}\text { 2-Tertiary butyl } \\
\text { phenol }\end{array}$ & 150.2 & 149.1 & 133.1 & 16 \\
\hline 10 & & $\begin{array}{l}\text { 3-Tertiary butyl } \\
\text { phenol }\end{array}$ & 150.2 & 149.2 & 133.1 & 16.1 \\
\hline 11 & & $\begin{array}{l}\text { 4-Tertiary butyl } \\
\text { phenol }\end{array}$ & 150.2 & 149.1 & 133.1 & 16 \\
\hline 12 & & $\begin{array}{l}\text { 4-Tertiary amyl } \\
\text { phenol }\end{array}$ & 164.3 & 162.9 & 133.1 & 29.8 \\
\hline 13 & & $\begin{array}{l}\text { 2-Secondary butyl } \\
\text { phenol }\end{array}$ & 150.2 & 149.2 & 119.1 & 30.1 \\
\hline
\end{tabular}


Table 1. Mass spectral fragmentation of propofol and structurally related phenols

\begin{tabular}{|c|c|c|c|c|c|c|}
\hline $\begin{array}{l}\text { Sample } \\
\text { number }\end{array}$ & Structure & Phenol & $\begin{array}{c}\text { Molecular } \\
\text { weight } \\
(\mathrm{g} / \mathrm{mol})\end{array}$ & $\begin{array}{l}\text { Quasi-molecular } \\
\text { Ion }[\mathrm{M}-\mathrm{H}]^{-}(\mathrm{m} / \mathrm{z})\end{array}$ & $\begin{array}{l}\text { Most abundant } \\
\text { product ion } \\
(\mathrm{m} / \mathrm{z})\end{array}$ & $\begin{array}{c}\text { Elimination } \\
\text { product } \\
\text { (mass) }\end{array}$ \\
\hline 14 & & $\begin{array}{l}\text { 4-Secondary butyl } \\
\text { phenol }\end{array}$ & 150.2 & 149.1 & 119.1 & 30 \\
\hline 15 & & 2-Ethyl phenol & 122.2 & 120.9 & 106.2 & 14.7 \\
\hline 16 & & 2-n-Propyl phenol & 136.2 & 135 & 106 & 29 \\
\hline 17 & & 4-n-Butyl phenol & 150.2 & 149.1 & 105.8 & 43.3 \\
\hline 18 & & 4-n-Pentyl phenol & 164.3 & 162.9 & 106.2 & 56.7 \\
\hline 19 & & 4-n-Heptyl phenol & 192.3 & 190.9 & 106.3 & 84.6 \\
\hline 20 & & $\begin{array}{l}\text { 2-Hydroxy phenol } \\
\text { (catechol) }\end{array}$ & 110.1 & 107.8 & 80.3 & 27.5 \\
\hline 21 & & 2-Methyl phenol & 108.1 & 106.9 & 92.3 & 14.6 \\
\hline 22 & & 3-Methyl phenol & 108.1 & 106.8 & 92.3 & 14.5 \\
\hline 23 & & 4-Methyl phenol & 108.1 & 106.8 & 92.3 & 14.5 \\
\hline 24 & & 4-Vinyl phenol & 120.2 & 119.1 & 93.1 & 26 \\
\hline
\end{tabular}

tioned above and an isocratic separation $(0.15 \mathrm{~mL} /$ $\min$ of $\mathrm{A}: \mathrm{B}=15: 85)$.

\section{Hybrid Quadrupole/Time of Flight} High Resolution Mass Spectrometry

Precise determination of the mass of product ions was carried out on a third mass spectrometer, an API QSTAR Pulsar hybrid quadrupole time-of-flight (QTOF) mass spectrometer (Applied Biosystems/
MDS Sciex, Foster City, CA) equipped with a Protana nanospray source (Protana Engineering A/S, Starmosegardsvej, Denmark). Normal mass spectra and product ion mass spectra were acquired in negative ion electrospray mode and externally calibrated against $[\mathrm{M}-\mathrm{H}]^{-}$and $\mathrm{SO}_{3}^{-}$fragment ions of a taurocholic acid standard at $m / z 514.2838$ and 79.9568, respectively. Calibration allowed for mass accuracies of $<30$ ppm. For collision-induced dissociation (CID), precursor ion selection was performed using the 
(a)

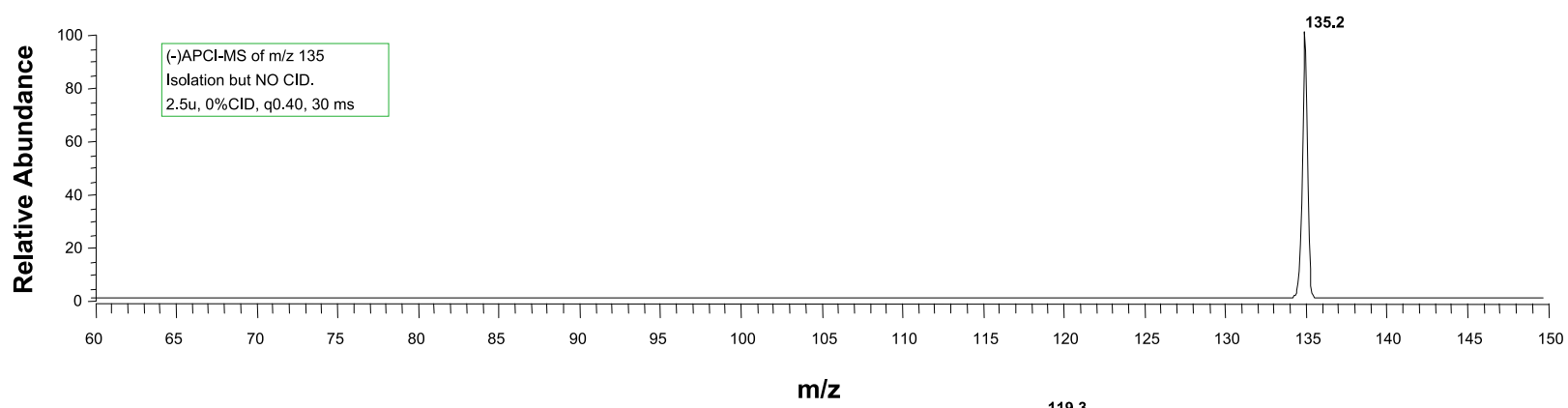

(b)

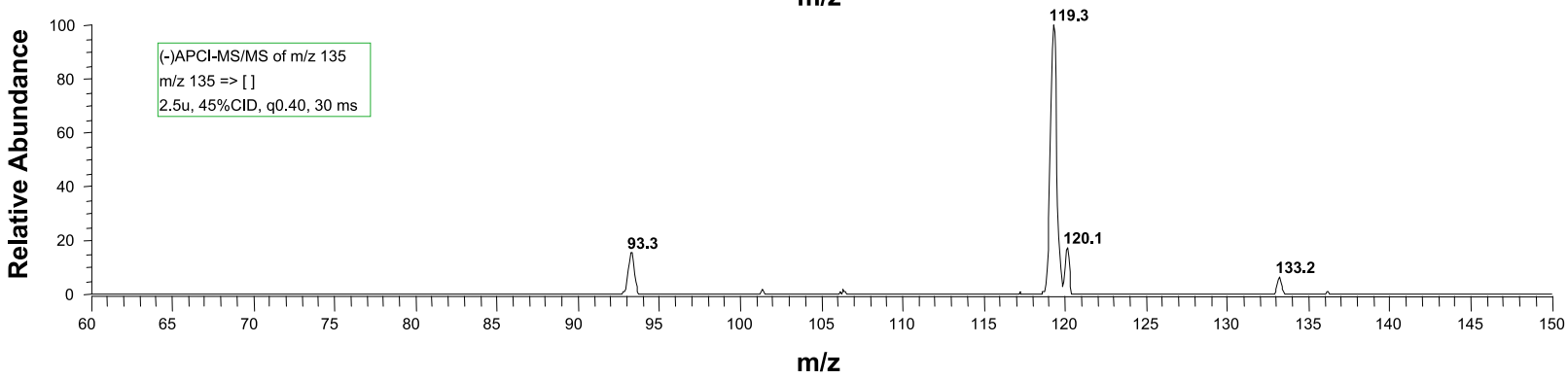

(c)

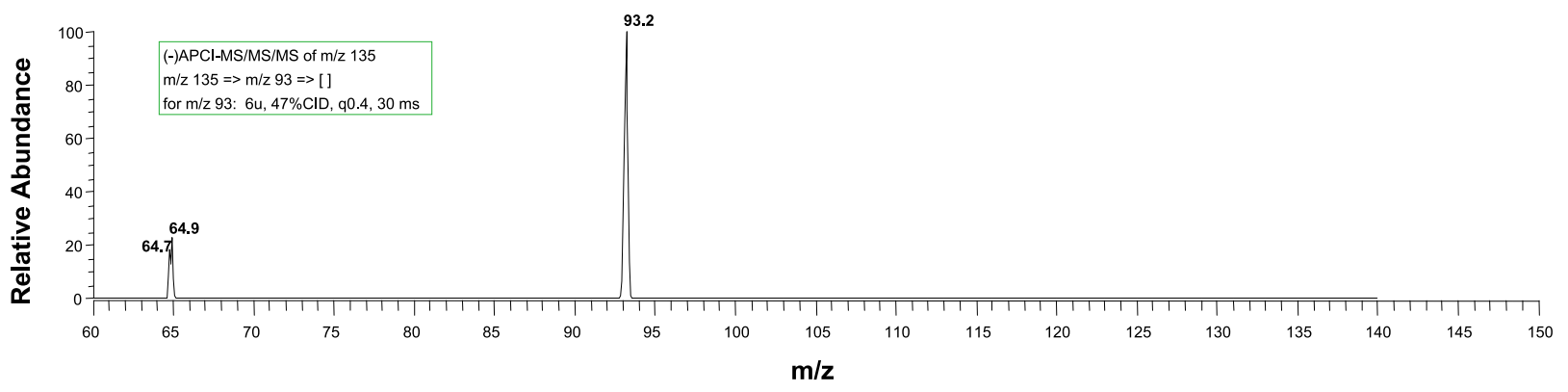

Figure 2. Mass spectral fragmentation of the $[\mathrm{M}-\mathrm{H}]^{-}$ion of 2-isopropyl-phenol with APCI in negative ion mode. (a) Normal mass spectrum ( $0 \%$ CID); (b) product ion spectrum at $45 \%$ CID yields product ions at $\mathrm{m} / \mathrm{z}$ 93, 119,120, and 133; (c) further fragmentation of $\mathrm{m} / \mathrm{z} 93$ yields $\mathrm{m} / \mathrm{z} 65$. These spectra were recorded with a Finnigan LCQ mass spectrometer.

quadrupole mass filter. Selected ions were fragmented in a subsequent quadrupole collision cell using nitrogen as the collision gas. Collision energy was $35 \mathrm{eV}$.

\section{Results and Discussion}

Limited information is available on the fragmentation of simple substituted phenols such as propofol. While published mass spectrometric methods for quantitation of propofol describe the parent-product ion pair used to identify and quantify propofol, they neither provide details of the fragmentation pattern nor address ${ }^{\circ}$ the ${ }^{\circ}$ mechanism ${ }^{\circ}$ of ${ }^{\circ}$ the ${ }^{\circ}$ fragmentation $\left[8,9,{ }^{\circ}, 15\right.$, 16]. ${ }^{\circ}$ Because ${ }^{\circ}$ the ${ }^{\circ}$ fragmentation ${ }^{\circ}$ behavior ${ }^{\circ}$ of ${ }^{\circ}$ the ${ }^{\circ}\left[\mathrm{M}^{\circ}-\right.$ $\mathrm{H}]^{-}$ion of propofol using APCI and ESI probes was not consistent with the expected loss of a methyl radical at the $\beta$ carbon of the isopropyl side chain, we performed a detailed study of the mass spectral fragmentation of propofol and structurally related phenols, both in the positive as well as negative ion mode. Our investigation revealed a unique and interesting fragmentation of these simply structured ions.

\section{Positive Ion Study}

Propofol was much less sensitively ionized in the positive ion mode than in the negative ion mode by either ${ }^{\circ} \mathrm{APCI}^{\circ}$ or $^{\circ} \mathrm{ESI}^{\circ}[15] .^{\circ}$ Similarly ${ }^{\circ}$ none ${ }^{\circ}$ of ${ }^{\circ}$ the ${ }^{\circ}$ other phenols used in this study was ionized efficiently in the positive ion mode. At typical working concentrations of $500 \mathrm{ng} / \mathrm{ml}$ used in this study the positive ion mode did not produce a detectable ion signal. These results are consistent with studies on the positive ion chemical ionization of phenols that showed that ionization by proton addition was inefficient due to the sterically crowded hydroxyl group as well as the slightly $^{\circ}$ acidic $^{\circ}$ nature ${ }^{\circ}$ of $^{\circ}$ these ${ }^{\circ}$ phenols $^{\circ}\left[15,{ }^{\circ} 16\right]$.

\section{Negative Ion Study}

In the negative ion mode, the product ion spectrum for propofol's $[\mathrm{M}-\mathrm{H}]^{-}$ion $(\mathrm{m} / \mathrm{z} 177)$ revealed an interesting $^{\circ}$ fragmentation ${ }^{\circ}$ behavior $^{\circ}\left(\right.$ Figure $\left.^{\circ} 1\right) . .^{\circ}$ Although ${ }^{\circ}$ the $[\mathrm{M}-\mathrm{H}]^{-}$ions of substituted phenols are typically easily fragmented and yield information-rich mass spectra, the product ion spectrum of $\mathrm{m} / \mathrm{z} 177$ was 


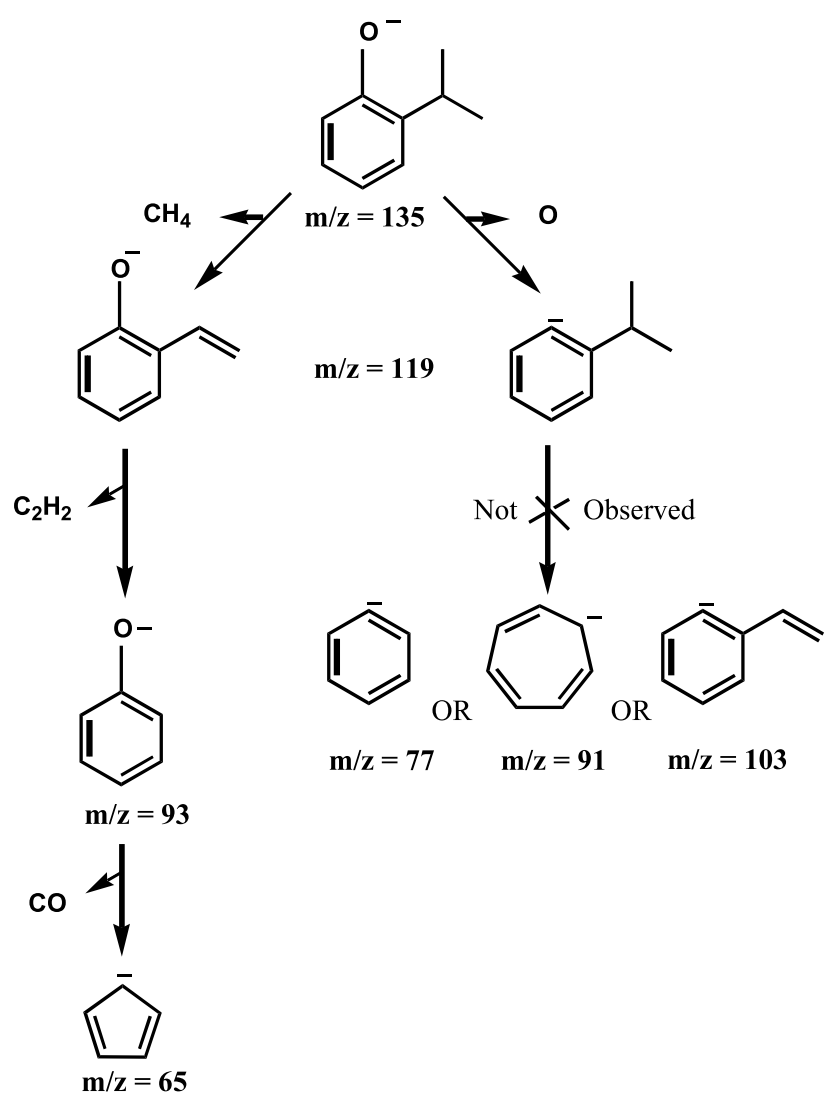

Scheme 2

noteworthy for the paucity of fragmentation products. It displayed only a single major product ion at $\mathrm{m} / \mathrm{z} 161$. All other product ions were nearly tenfold less abundant. Such a predominance of the ion $\mathrm{m} / \mathrm{z} 161$ was found despite the use of APCI MS/MS conditions that allow major decomposition processes, namely collision energies from 25 to $30 \mathrm{eV}$ and nitrogen pressures sufficient for multiple collisions.

Even more interesting was the characterization of the neutral loss. In the case of alkyl substituted phenols, cleavage of the $\beta$ carbon bond of the substituent to the phenyl ${ }^{\circ}$ ring $^{\circ}$ is ${ }^{\circ}$ well $^{\circ}$ documented $^{\circ}[22]^{\circ}$ and $^{\circ}$ always ${ }^{\circ}$ gives the major fragment ion. Thus, the loss of a methyl radical from the isopropyl side chain was expected to dominate the product ion spectrum of propofol. The major elimination product (nominal mass 16), however, is not consistent with the loss of a methyl radical (nominal mass 15). The loss of 16 mass units could be explained by the loss of either a methane molecule or an oxygen atom from the $[\mathrm{M}-\mathrm{H}]^{-}$parent ion. To ascertain the structure of the product ion $(\mathrm{m} / \mathrm{z} 161)$, the abundance of $\mathrm{m} / \mathrm{z} 161$ was increased by raising the declustering potential to $-90 \mathrm{~V}$ to induce so-called in-source fragmentation. Subsequent fragmentation at a collision energy of $45 \mathrm{eV}$ resulted in a mass spectrum with major identifiable peaks at $\mathrm{m} / \mathrm{z} 145,119$, and 65 (Figure $\left.^{\circ} 1 \mathrm{c}\right)^{\circ}$ which $^{\circ}$ correspond $^{\circ}$ to $^{\circ}$ the $^{\circ}$ fragmentation products of the $[\mathrm{M}-\mathrm{H}]^{-}$ion of propofol shown in Scheme $\mathbf{1}$ and are corroborated by the fragmentation experiments on 2-isopropyl phenol discussed below. Because of less abundance of ions at $m / z 143,89$, and 67, these were not assigned a structure.

To ascertain the identity of the proposed neutral loss $(\mathrm{m} / \mathrm{z} 16)$ in the fragmentation of propofol's $[\mathrm{M}-\mathrm{H}]^{-}$ ion, structurally related phenols were subjected to CID under conditions similar to those for propofol. Some highly substituted phenols required higher collision energy from 45 to $55 \mathrm{eV}$ for fragmentation. The results of these ${ }^{\circ} \mathrm{CID}^{\circ}$ studies ${ }^{\circ}{ }^{\circ}{ }^{\circ}$ shown ${ }^{\circ}$ in ${ }^{\circ}$ able 1 . Phenols ${ }^{\circ}$ that have only methyl groups in the $\beta$ position of the substituent (sample numbers 1-11) all show the most prominent product ion consistent with a neutral loss of

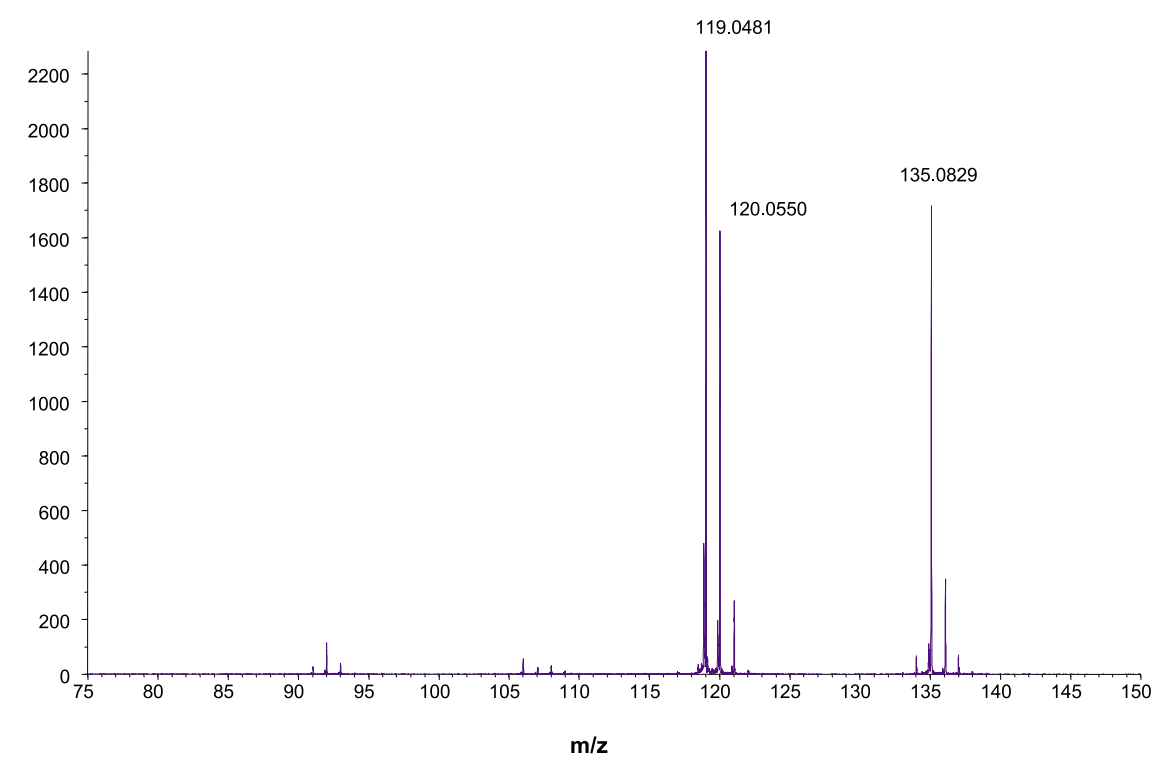

Figure 3. High resolution product ion spectrum of $m / z$ 135, the $[\mathrm{M}-\mathrm{H}]^{-}$ion of 2-isopropyl phenol. There are two distinct product ions at $m / z 119$ and 120 . 


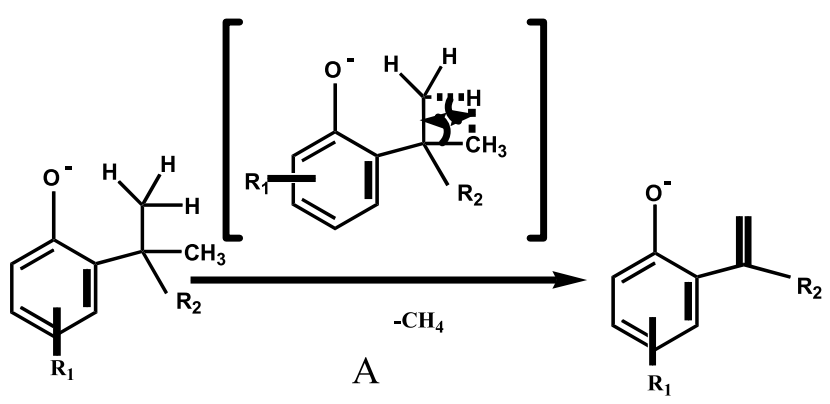

(a)
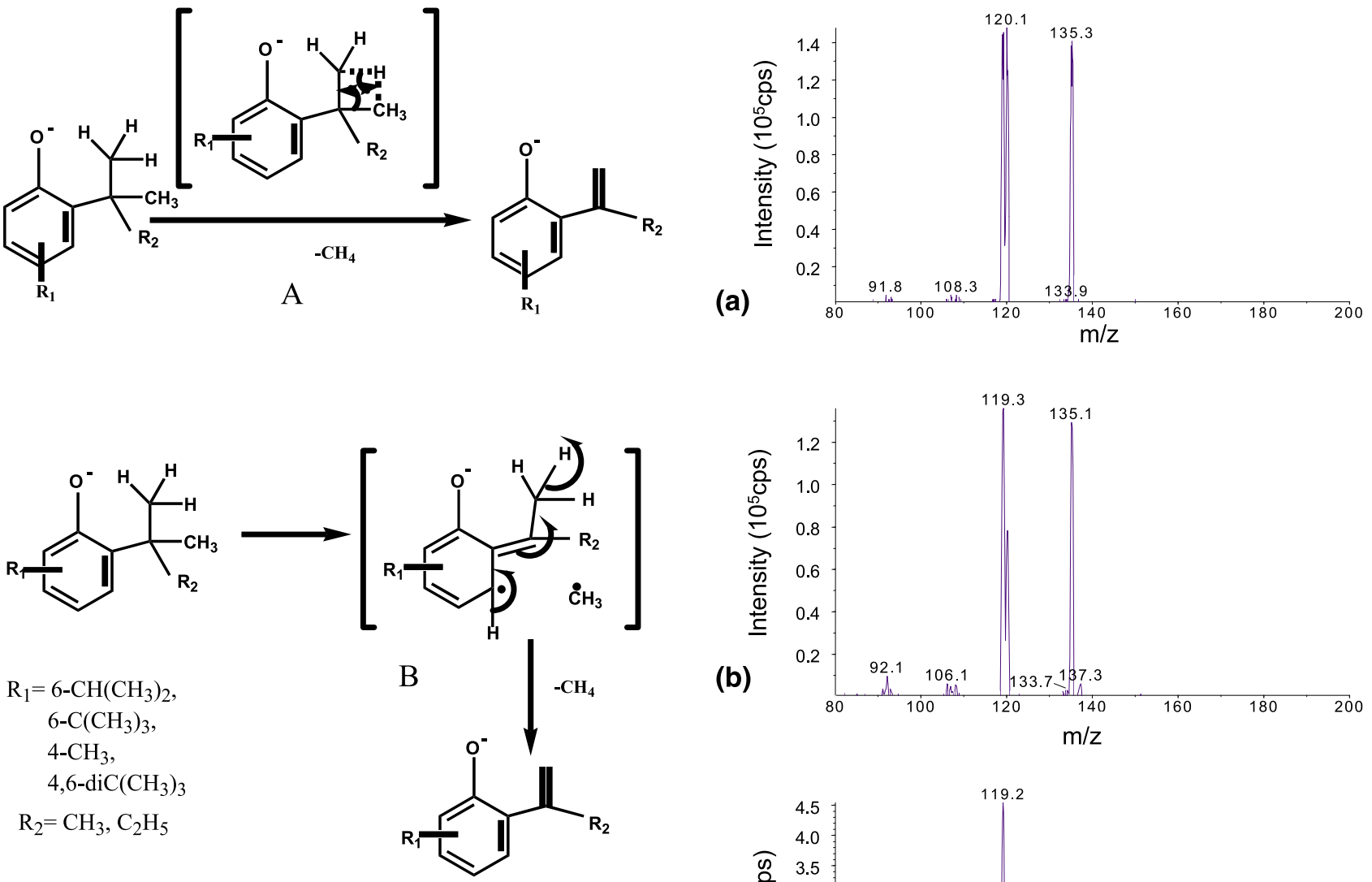

Scheme 3

$m / z 16$. In the case of secondary butyl and tertiary amyl phenols (sample numbers 12-14), which have a methyl as well as an ethyl group in the $\beta$ position, the most prominent product ion was formed by the loss of $\mathrm{m} / \mathrm{z}$ 30 , which may correspond to a loss of ethane rather than methane.

Table $^{\circ} 1^{\circ}$ also $^{\circ}$ shows $^{\circ}$ indirect ${ }^{\circ}$ evidence $^{\circ}$ for ${ }^{\circ}$ the ${ }^{\circ}$ proposed loss of methane as opposed to oxygen from the initial phenol. As could be expected from the methyl and the ethyl substituted phenols (sample numbers $21-23$ and 15 , respectively), which have no $\beta$ methyl group, daughter ions were formed by the loss of $m / z 15$, which could be attributed to a methyl group. Similarly, catechol (sample number 20) did not show loss of $\mathrm{m} / \mathrm{z}$ 16. These findings support the contention that the loss of $\mathrm{m} / \mathrm{z} 16$ does not correspond to a loss of an oxygen atom from the phenol, because oxygen was present in all these phenols, whereas a methyl group in the $\beta$ position of the substituent was not. The proposed loss of methane was confirmed by doing further product ion scans of 2-isopropyl phenol.

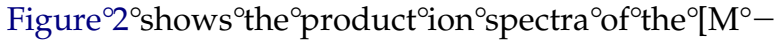
$\mathrm{H}]^{-}$ion of 2-isopropyl phenol. If the loss of $\mathrm{m} / \mathrm{z} 16$ from isopropyl phenol's $[\mathrm{M}-\mathrm{H}]^{-}$ion corresponds to an oxygen atom, then further fragmentation of the $\mathrm{m} / \mathrm{z} 119$ product ion should lead to a product ion at $\mathrm{m} / \mathrm{z} 91$ because of the loss of $\mathrm{C}_{2} \mathrm{H}_{4}$ (Scheme 2). Conversely, if the loss of $m / z 16$ from the $[\mathrm{M}-\mathrm{H}]^{-}$ion corresponds to the loss of methane, further fragmentation of the prod-
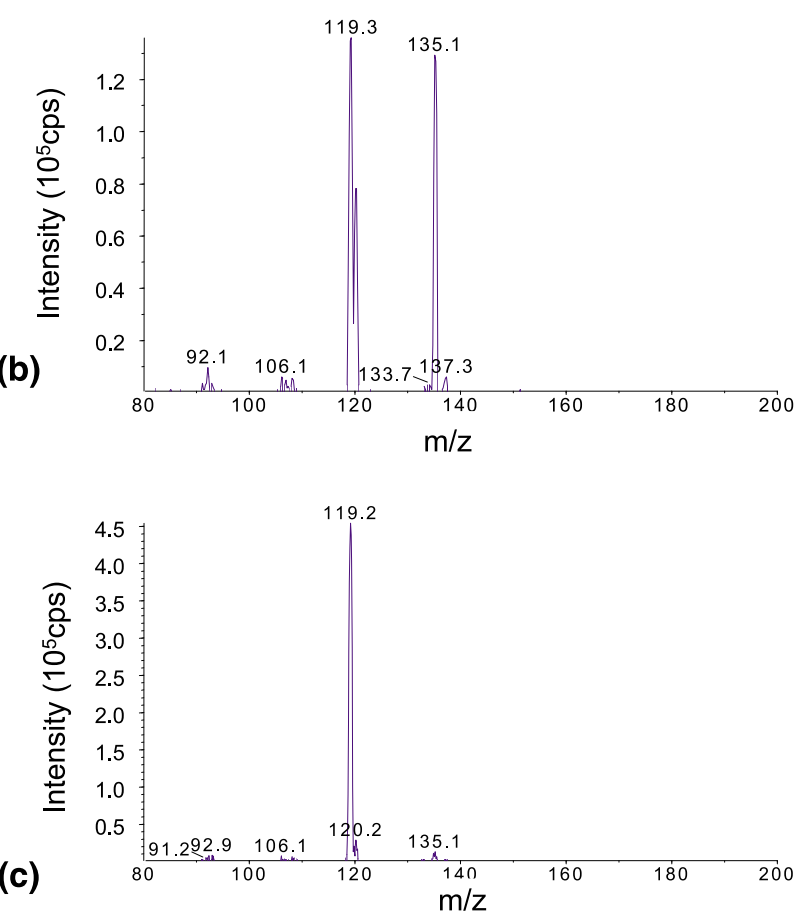

Figure 4. Product ion spectrum of the $[\mathrm{M}-\mathrm{H}]^{-}$ion of 3isopropyl phenol at increasing levels of collision-induced dissociation (a) collision energy $25 \mathrm{eV}$ and collision gas supply pressure 2 psi; (b) collision energy $25 \mathrm{eV}$ and collision gas supply pressure $6 \mathrm{psi}$; (c) collision energy $30 \mathrm{eV}$ and collision gas supply pressure 6 psi.

uct ion should produce product ions of $\mathrm{m} / \mathrm{z} 93$ (loss of $\mathrm{C}_{2} \mathrm{H}_{2}$ ), which in turn could lose $\mathrm{CO}$ (nominal mass 28 ) to give rise to a product ion at $\mathrm{m} / \mathrm{z} 65$. The proposed

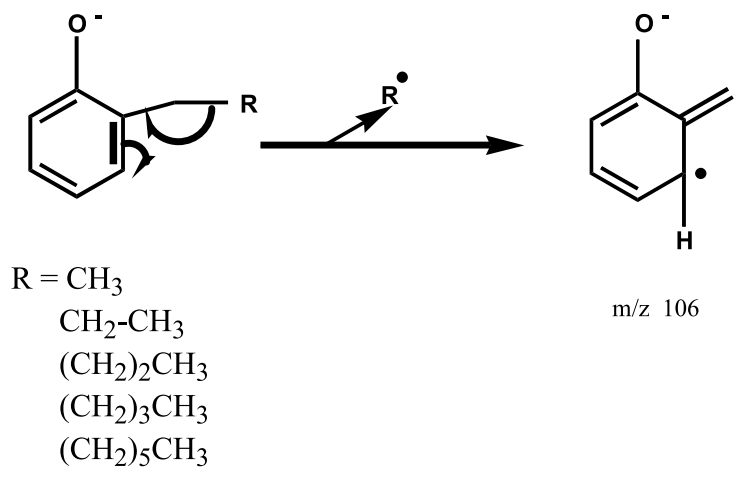

Scheme 4 
Table 2. Intensities of the most abundant product ions $\left[\mathrm{M}-\mathrm{H}-\mathrm{CH}_{4}\right]^{-}$of ortho, meta, and para substituted phenols with APCI in negative ion mode

\begin{tabular}{|c|c|c|c|c|c|c|}
\hline Phenol & $\begin{array}{l}\text { Parent ion } \\
{\text { [M-H }]^{-}}_{(\mathrm{m} / \mathrm{z})}\end{array}$ & $\begin{array}{c}\text { Collision } \\
\text { energy } \\
\text { (eV) }\end{array}$ & $\begin{array}{l}\text { Most abundant } \\
\text { product ion } \\
(\mathrm{m} / \mathrm{z})\end{array}$ & $\begin{array}{c}\text { Intensity of } \\
\text { parent ion } \\
\left(10^{4} \mathrm{cps}\right)\end{array}$ & $\begin{array}{l}\text { Intensity of } \\
\text { product } \\
\text { ion }\left(10^{4}\right. \\
\mathrm{cps})\end{array}$ & $\begin{array}{c}\text { Intensity } \\
\text { ratio } \\
\text { product/ } \\
\text { parent }\end{array}$ \\
\hline 2-Isopropyl phenol & 135.0 & 35 & 118.9 & 2300 & 4 & 0.002 \\
\hline 3-Isopropyl phenol & 135.0 & 35 & 119.1 & 2400 & 280 & 0.117 \\
\hline 2-Tertiary butyl phenol & 149.0 & 35 & 133.1 & 630 & 15 & 0.024 \\
\hline 3-Tertiary butyl phenol & 149.0 & 35 & 133.1 & 2600 & 390 & 0.15 \\
\hline 4-Tertiary butyl phenol & 149.0 & 35 & 133.1 & 2000 & 28 & 0.014 \\
\hline 2,6-Ditertiary butyl phenol & 205.1 & 35 & 189.2 & 3000 & 20 & 0.007 \\
\hline 3,5-Ditertiary butyl phenol & 205.0 & 35 & 189.2 & 3400 & 400 & 0.118 \\
\hline
\end{tabular}

structure for $m / z 119$ was further supported by comparing its product ions with the product ions of 4 -vinyl phenol, fragmented under identical conditions (data not shown). These experiments also produced daughter ions at $m / z 93$ and 65, two common fragmentation peaks for ${ }^{\circ}$ the ${ }^{\circ}\left[\mathrm{M}^{\circ}-{ }^{\circ} \mathrm{H}\right]^{-}{ }^{\circ}$ ions $^{\circ}$ of $^{\circ}$ most $^{\circ}$ phenols ${ }^{\circ}[22] .^{\circ}$ As $^{\circ}$ is eviden $^{\circ}{ }^{\circ}$ from $^{\circ}$ Figure $^{\circ} 2,{ }^{\circ}$ there ${ }^{\circ}$ were $^{\circ}$ no $^{\circ}$ product $^{\circ}$ ions corresponding to $\mathrm{m} / \mathrm{z} 103,91$, or 77 , whereas there is a product ion at $\mathrm{m} / \mathrm{z}$ 93. Taken together, these findings support the assumption of a loss of methane from the initial phenols.

Further evidence for the proposed loss of 16 as a methane molecule, as opposed to an oxygen atom, was provided by recording high resolution product ion mass spectra of the $[\mathrm{M}-\mathrm{H}]^{-}$ion of 2-isopropyl phenol $\left[\mathrm{m} / \mathrm{z} 135.0829^{\circ}\left(14.1^{\circ} \mathrm{ppm}^{\circ} \text { error) }\right]^{\circ}\right.$ (Figure ${ }^{\circ}$ 3). ${ }^{\circ}$ Precise determination of the mass of the product ion at $\mathrm{m} / \mathrm{z} 119$ yields a mass of 119.0481 (13.4 ppm error). This measurement supports the ionic formula of $\mathrm{C}_{8} \mathrm{H}_{7} \mathrm{O}^{-}$formed by the loss of methane from the $[\mathrm{M}-\mathrm{H}]^{-}$ion of 2-isopropyl phenol with a calculated mass of 119.0497 $(\Delta=0.0016$, error of $13.4 \mathrm{ppm})$, rather than $\mathrm{C}_{9} \mathrm{H}_{11}^{-}$ formed by the loss of oxygen with a calculated mass of $119.0861(\Delta=0.0380$, error of $319 \mathrm{ppm})$. Furthermore, the product ion attributable to mass loss of 15 at $\mathrm{m} / \mathrm{z}$ 120.0550 (20.8 ppm) can not be explained by the loss of a single oxygen atom, but is entirely consistent with the intermediary fragmentation product based on the twostep fragmentation mechanism for the loss of methane discussed below.

Two possible mechanisms for the loss of $m / z 16$ upon $\mathrm{CID}$ of the $[\mathrm{M}-\mathrm{H}]^{-}$ion of various substituted phenols (Table 1, 'samplenumbers $\left.{ }^{\circ}-11\right)^{\circ}$ are ${ }^{\circ}$ shown ${ }^{\circ}{ }^{\circ}{ }^{\circ}$ cheme 3. One is a simple concerted four-centered elimination of methane (Scheme 3a) and the other is a stepwise elimination involving an initial cleavage to form an intermediate ion-molecule complex (Scheme $\mathbf{3 b}$ ) and a subsequent proton transfer within the complex, which is similar to the mechanisms reported for the elimination of methane from alkoxide ions in the gas phase [19-21]..$^{\circ}$ Consistent ${ }^{\circ}$ with $^{\circ}$ the ${ }^{\circ}$ stepwise ${ }^{\circ}$ fragmentation mechanism, product ions corresponding to the intermediate radical ion $\mathrm{B}$ were seen for almost all phenols when product spectra were acquired at lower collision energies of 20 to $25 \mathrm{eV}$. Such intermediate product ions can not be explained by the concerted mechanism (Scheme 3a). However, in none of these cases was it possible to observe the ion radical $B$ as the major product ${ }^{\circ}$ ion..$^{\circ}$ For $^{\circ}$ example $^{\circ}$ in ${ }^{\circ}$ the ${ }^{\circ}$ case $^{\circ}$ of ${ }^{\circ} 3-{ }^{\circ}$ isopropyl phenol $^{\circ}$ (Figure $\left.{ }^{\circ} 4\right),{ }^{\circ}$ the ${ }^{\circ}$ product ${ }^{\circ}$ ion ${ }^{\circ}$ arising ${ }^{\circ}$ from ${ }^{\circ}$ the ${ }^{\circ}$ loss of a methyl radical at $\mathrm{m} / \mathrm{z} 120$ was formed along with the product ion at $m / z 119$ in equal intensity when the spectrum was recorded at a collision energy of $25 \mathrm{eV}$ and $^{\circ} \mathrm{a}^{\circ}$ collision ${ }^{\circ}$ gas $^{\circ}$ supply ${ }^{\circ}$ pressure ${ }^{\circ}$ of $2^{\circ}$ psi $^{\circ}$ (Figure $4 a$ ). An increase in the collision gas supply pressure from 2 to $6 \mathrm{psi}$ at the same collision energy increased the intensity of the product ion at $\mathrm{m} / \mathrm{z} 119$ at the expense of the ${ }^{\circ}$ product $^{\circ}$ ion $^{\circ}{ }^{\circ} t^{\circ} \mathrm{m} / z 120^{\circ}$ (Figure $4 \mathrm{~b}$ )..$^{\circ}$ As ${ }^{\circ}$ the ${ }^{\circ}$ collision energy increased to $30 \mathrm{eV}$ the product ion at $\mathrm{m} / \mathrm{z} 119$ became ${ }^{\circ}$ the ${ }^{\circ}$ major $^{\circ}$ ion $^{\circ}$ peak $^{\circ}$ (Figure ${ }^{\circ} 4 \mathrm{c}$ ). ${ }^{\circ}$ Encouraged ${ }^{\circ}$ by this observation, we presumed that fragmentation of a phenol with only one substitution at the $\beta$ position would allow us to observe an ion radical similar to this intermediate ion radical at $\mathrm{m} / \mathrm{z} 120$ as the predominant ion peak, because there will be no $\beta$ hydrogen available for further loss of an $\mathrm{H}$ radical. With this strategy, CID of the $[\mathrm{M}-\mathrm{H}]^{-}$ion of n-ethyl, n-propyl, n-butyl, n-pentyl, and n-heptyl phenols was attempted. The product ion spectra showed, as expected, $m / z 106$ as the

(a)

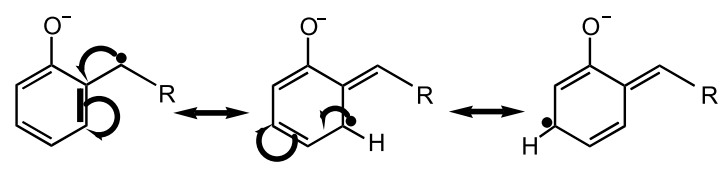

(b)

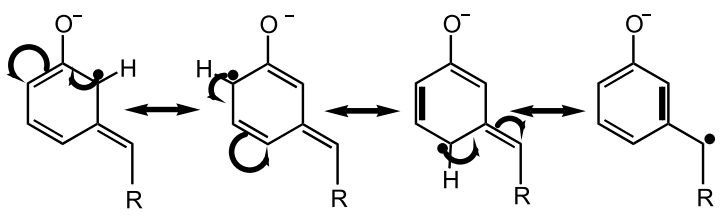

(c)

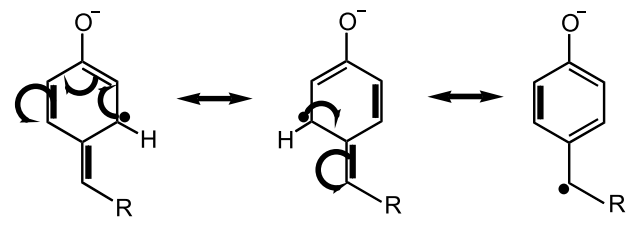

Scheme 5 

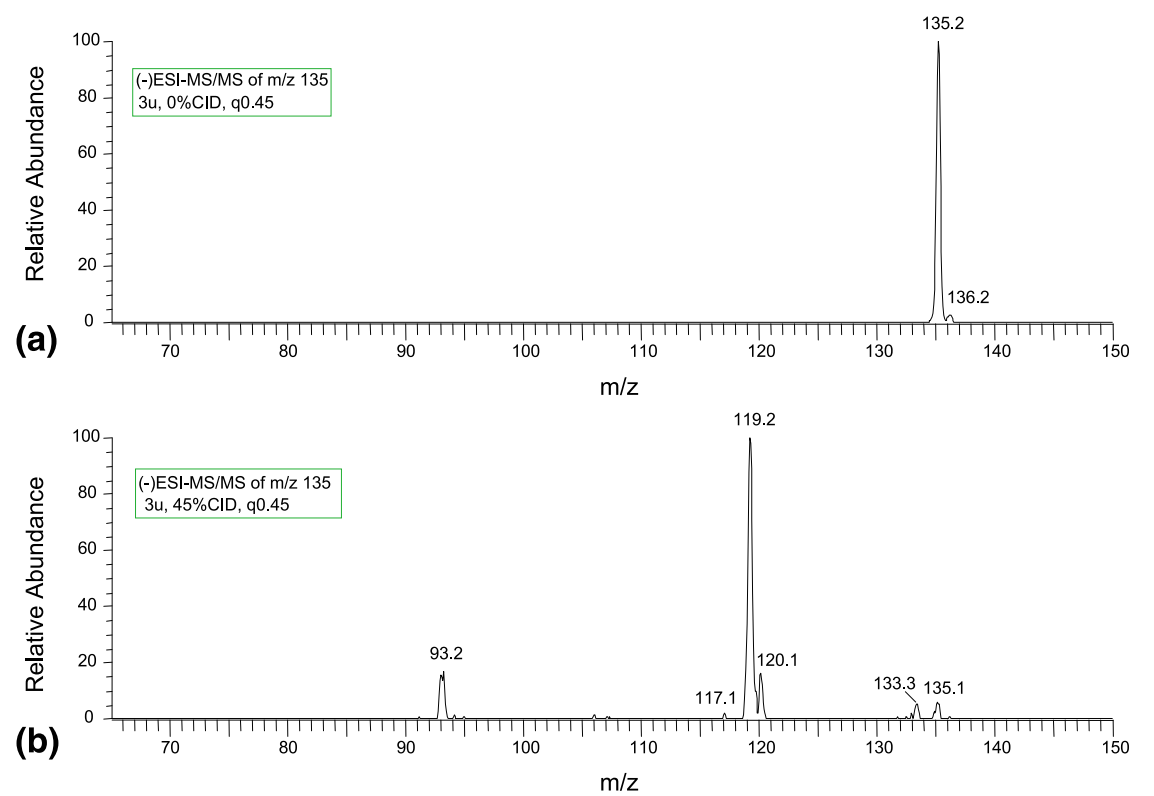

Figure 5. Mass spectral fragmentation of the $[\mathrm{M}-\mathrm{H}]^{-}$ion of 2-isopropyl phenol using electrospray

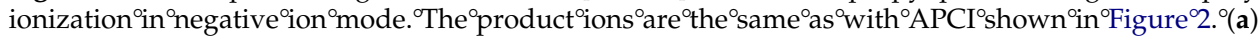
Normal mass spectrum; (b) product ion spectrum of $\mathrm{m} / \mathrm{z} 135$ at $45 \%$ CID. These spectra were recorded with a Finnigan LCQ mass spectrometer.

only $^{\circ}$ major $^{\circ}$ product $^{\circ}$ ion $^{\circ}\left(\right.$ Table $^{\circ} 1,{ }^{\circ}$ sample $^{\circ}$ numbers 15-19). The fragmentation process is shown in Scheme 4.

The two-step mechanism for the loss of methane by the sequential loss of $\mathrm{CH}_{3}$ and $\mathrm{H}$ radicals was further supported by comparing the abundances of product ions formed from different ortho, meta, and para substituted ${ }^{\circ}$ phenols. $^{\circ}$ Table $^{\circ} 2^{\circ}$ shows $^{\circ}$ the ${ }^{\circ}$ intensities ${ }^{\circ}$ of ${ }^{\circ}$ the product ions formed by the loss of methane from the $[\mathrm{M}-\mathrm{H}]^{-}$ion of phenols substituted at ortho, meta, and para positions with the same substituents. Compared to product ions from ortho and para substituted phenols, those from meta substituted phenols were more stable and always formed in greater relative abundance (typically 20-fold more intense) irrespective of the type of substituent present. This finding is consistent with the proposed mechanism for the fragmentation shown in Scheme 3 because the intermediate radical ions resulting from meta substituted phenols will have more resonance structures (Scheme 5) and are therefore more likely to form and are more stable.

CID of the $[\mathrm{M}-\mathrm{H}]^{-}$ion of each of these phenols was also performed after ionization with ESI in the negative ion mode. For all phenols, the pattern of fragmentation was almost the same as after ionization with APCI. Figure ${ }^{\circ}{ }^{\circ}$ shows ${ }^{\circ}$ product ${ }^{\circ}$ ion ${ }^{\circ}$ spectra ${ }^{\circ}$ of ${ }^{\circ}$ he $\left[\mathrm{M}^{\circ}-{ }^{\circ} \mathrm{H}\right]^{-}{ }^{\circ}$ ion obtained from ESI of 2-isopropyl phenol. The product ions are identical to those obtained in APCI MS/MS shown ${ }^{\circ}$ in $^{\circ}$ Figure $^{\circ} 2 .{ }^{\circ}$ These $^{\circ}$ results ${ }^{\circ}$ further ${ }^{\circ}$ support ${ }^{\circ}$ the fragmentation pathways for the $[\mathrm{M}-\mathrm{H}]^{-}$ion of simple substituted phenols depicted in Schemes 3 and 4 . APCI was selected over ESI as the source of choice for the LC/MS/MS assay for propofol for three major reasons. First, APCI is a more predictable and robust ion source for small compounds that are thermally stable and volatile. Second, APCI is more compatible with high HPLC flow rates than ESI. Finally, ESI sensitivity is greatest at low flow rates but it can suffer from unreliable detection efficiency for small drug compounds [23].

\section{Conclusions}

The mass spectral fragmentation of the $[\mathrm{M}-\mathrm{H}]^{-}$ion of propofol involves the sequential loss of a methyl radical and a hydrogen radical in a two-step process to give the most intense product ion at $m / z 161$. This two-step process was also the preferred mode of fragmentation for the $[\mathrm{M}-\mathrm{H}]^{-}$ion of structurally similar phenols with branched alkyl substituents. Phenols with a straight chain alkyl substituent, in contrast, underwent $\beta$ elimination of the alkyl radical irrespective of the length of the alkyl chain, yielding the most intense product ion at $\mathrm{m} / \mathrm{z} 106$. This product ion represents a special case of a stable radical for the two-step process described for branched side chains because further elimination of a hydrogen radical from the $\beta$ carbon is not possible.

\section{Acknowledgments}

The authors greatly appreciate financial support from the Joachim S. Gravenstein, M.D. endowed chair of Anesthesiology during this work. CNS was supported by the National Aeronautics and Space Administration grant NNJ04HF74G. 


\section{References}

1. Shafer, A.; Doze, V. A.; Shafer, S. L.; White, P. F. Pharmacokinetics and Pharmacodynamics of Propofol Infusions During General Anesthesia. Anesthesiology 1988, 69, 348-356.

2. Dailland, P.; Cockshott, I. D.; Lirzin, J. D.; Jacquinot, P.; Jorrot, J. C.; Devery, J.; Harmey, J. L.; Conseiller, C. Intravenous Propofol During Cesarean Section: Placental transfer, Concentrations in Breast Milk, and Neonatal Effects. A Preliminary Study. Anesthesiology 1989, 71, 827-834.

3. Albanese, J.; Martin, C.; Lacarelle, B.; Saux, P.; Durand, A.; Gouin, F. Pharmacokinetics of Long-Term Propofol Infusion Used for Sedation in ICU Patients. Anesthesiology 1990, 73, 214-217.

4. Marsh, B.; White, M.; Morton, N.; Kenny, G. N. Pharmacokinetic Model Driven Infusion of Propofol in Children. Br. J. Anesth. 1991, 67, 41-48.

5. Pavan, I.; Buglione, E.; Massiccio, M.; Gregoretti, C.; Burbi, L.; Berardino, M. Monitoring Propofol Serum Levels by Rapid and Sensitive Reversed-Phase High-Performance Liquid Chromatography During Prolonged Sedation in ICU Patients. J. Chromatogr. Sci. 1992, 30, 164-166.

6. Plummer, G. F. Improved Method for the Determination of Propofol in Blood by High-Performance Liquid Chromatography with Fluorescence Detection. J. Chromatogr. 1987, 421, 171-176.

7. Mazzi, G.; Schinella, M. Simple and Practical High-Performance Liquid Chromatographic Assay of Propofol in Human Blood by Phenyl Column Chromatography with Electrochemical Detection. J. Chromatogr. 1990, 528, 537-541.

8. Elbast, W.; Guitton, J.; Desage, M.; Deruaz, D.; Manchon, M.; Brazier, J. L. Comparison Between Gas ChromatographyAtomic Emission Detection and Gas Chromatography-Mass Spectrometry for the Assay of Propofol. J. Chromatogr. B. Biomed. Appl. 1996, 686, 97-102.

9. Stetson, P. L.; Domino, E. F.; Sneyd, J. R. Determination of Plasma Propofol Levels Using Gas Chromatography-Mass Spectrometry with Selected-Ion Monitoring. J. Chromatogr. 1993, 620, 260-267.

10. Fujita, A.; Higuchi, J.; Nagai, T.; Tokudome, S.; Sakio, H. A Simple Method for Detecting Plasma Propofol. Anesth. Analg. 2000, 90, 1452-1454.

11. Bajpai, L.; Varshney, M.; Seubert, C. N.; Dennis, D. M. A New Method for the Quantitation of Propofol in Human Plasma: Efficient Solid-Phase Extraction and Liquid Chromatography/ APCI-Triple Quadrupole Mass Spectrometry Detection. J. Chromatogr. B. Analyt. Technol. Biomed. Life Sci. 2004, 810, 291-296.
12. Binkley, R. W.; Tevesz, M. J. S.; Winnik, W. Reactions of Phenoxide Ion in the Gas Phase. J. Org. Chem. 1992, 57, 5507-5509.

13. Tiernan, T. O.; Chang, C.; Cheng, C. C. Formation and Reactions of Negative Ions Relevant to Chemical Ionization Mass Spectrometry. I. CL Mass Spectra of Organic Compounds Produced by F-Reactions. Environ. Health Perspect. 1980, 36, 47-62.

14. Busch, K. L.; Norstrom, A.; Nilsson, C. A.; Bursey, M. M.; Hass, J. R. Negative Ion Mass Spectra of Some Polychlorinated 2-Phenoxyphenols. Environ. Health Perspect. 1980, 36, $125-132$.

15. Zhang, H.; Wang, P.; Bartlett, M. G.; Stewart, J. T. HPLC Determination of Cisatracurium Besylate and Propofol Mixtures with LC-MS Identification of Degradation Products. J. Pharm. Biomed. Anal. 1998, 16, 1241-1249.

16. Wang, P.; Zhang, H.; Stewart, J. T.; Bartlett, M. G. Simultaneous Detection of Cisatracurium; Its Degradation Products and Propofol using Positive Ion Detection Followed by Negative Ion Detection in a Single LC/MS Run. J. Pharm. Biomed. Anal. 1998, 17, 547-553.

17. Krokhin, A. V.; Chizhow, O. S.; Mikheeva, N. N.; Ershov, V. V.; Volod'kin, A. A. Mass Spectra of Sterically Hindered Phenols. Izvestiya Akademii Nauk SSSR, Seria Khimicheskaya 1975, 10, 2334-2337.

18. Kadentsev, V.; Krokhin, A. V.; Chizhow, O. S.; Ershov, V. V. Behavior of Sterically Hindered Phenols in Chemical Ionization in Methane. Izvestiya Akademii Nauk SSSR, Seria Khimicheskaya 1978, 11, 2532-2538.

19. Tumas, W.; Foster, R. F.; Pellerite, M. J.; Brauman, J. I. A Stepwise Mechanism for Gas-Phase Unimolecular Ion Decompositions. Isotope Effects in the Fragmentation of tert-Butoxide Anion. J. Am. Chem. Soc. 1987, 109, 961-970.

20. Tumas, W.; Foster, R. F.; Brauman, J. I. Mechanistic Studies of Gas Phase Negative Ion Unimolecular Decompositions. Alkoxide Anions. J. Am. Chem. Soc. 1988, 110, 2741-2722.

21. Hayes, R. N.; Sheldon, J. C.; Bowie, J. H.; Lewis, D. E. Elimination of Molecular Hydrogen and Methane from Collision-Activated Alkoxide Negative Ions in the Gas Phase. An ab Initio and Isotope Effect Study. Aust. J. Chem. 1985, 38, 1197-1208.

22. Silverstein, R. M.; Webster, F. X. Spectrometric Identification of Organic Compounds, 6th ed.; John Wiley and Sons: New York, NY, 1997; p 20

23. Hanold, K. A.; Fischer, S. M.; Cormia, P. H.; Miller, C. E.; Syage, J. A. Atmospheric Pressure Photoionization. 1. General Properties for LC/MS. Anal. Chem. 2004, 76, 2842-2851. 